\title{
Assessment of the HIV/AIDS Impact on the Nigerian Economy Performance: An Empirical Analysis
}

Okoh Abo Sunday, Ojiya Emmanuel Ameh* and Amadi Uchechukwu

Department of Economics, Federal University Wukari, Nigeria

\begin{abstract}
The HIV-AIDS pandemic is a problem affecting several African and Latin American countries including Nigeria. It is a scourge that has adversely affected the productivity levels of families, communities and eventually economies. This study is therefore designed to evaluate the Impact of HIVIAIDS on the Performance of the Nigerian Economy. Using annual time series data sourced from the World Bank Database, Central Bank of Nigeria statistical bulletin and econometric tools of analysis, findings indicated that all the variables defined in the model were stationary and there exists a unique long run relationship between the dependent and independent variables in the model. Furthermore, the research concluded that HIVIAIDS had a significant negative impact on productivity and by implication economic growth. Similarly, government spending on health had a significant positive impact on economic growth in Nigeria during the period studied. The study thus recommends that the government should urgently elicit the cooperation of all relevant stakeholders and set up policies for the prevention of the estimated output loss that could result if the disease prevalence is not controlled. Finally, infected individuals should have access to anti-retroviral drugs at the primary health centres to reduce time and resources in care-giving.
\end{abstract}

\section{Keywords: HIV; AIDS; Cointegration; OLS; Economic growth}

\section{Background of the Study}

The threat of HIV continues to be one of the most dreaded health challenges in the world since 1980s. The global AIDS response revealed that the national meridian HIV prevalence infection in Nigeria as $4.1 \%$. HIV/AIDS affects both the old, young, men and women in the society and in fact affect the productivity of every nation. From inception the disease has destroyed lives, families and societies. HIV and AIDS deplete human immune system which kills the white blood cells resulting to death of its victims. The epidemic has become a serious issue globally. It is no longer only a health issue but a substantial threat to economic growth, imposing a heavy burden, first on families, communities and eventually on the economy.

The first description of HIV/AIDS in Nigeria was discovered from a sexually active 13 year old girl in 1986 that tested positive to HIV [1]. The record led to the establishment of a national expert advisory committee and subsequently the National HIV and AIDS and STDs Control Programme, which had the responsibility for the national health response to HIV and AIDS in Nigeria. The impact of HIV/AIDS is on every facet of the economy, in fact, not only on productivity even the impact boils down to economic growth. In Nigeria for instance, it affects sectors like labour productivity (force), agricultural production, productivity in general or national economy.

Productivity of a country is very fundamental and desirable phenomenon in the development process that every nation strives to achieve and maintain. This is because HIV/AIDS poses such loss as the productivity among HIV patients due to sickness and death, production loss due to care givers of HIV/AIDS patients, cost of management of AIDS patients, lack of self-esteem among others. Productivity in Nigeria requires healthy manpower and other stimulating factors such as strong capital formation, real investment, technical progress and discipline. With the presence of HIV and AIDS in Nigeria, economic growth tends to be suppressed, below the levels of actual potential economic growth in Nigeria [2]

\section{Problem statement, objectives and hypothesis}

HIV/AIDS epidemics are highly devastating and pose a serious threat on the economy most especially on the productivity of a country. It is estimated that eleven persons becomes infected every minute representing some 15,000 new infections every day or more than 5.4 million for the entire year. Out of the 2.9 million HIV and AIDS related death in 2003, 2.2 million were from Sub-Saharan Africa which is the most affected region in the world. Globally 33.2 million affected persons are from Africa among which 2.95 million adults and children are estimated to be living with HIV and AIDS in Nigeria. The country was second worst nation in terms of HIV infection in the world after South Africa (FMOH, 2010). In 2004, over 200,000 Nigerian children were made orphans due to the epidemic [3]. Deductively HIV/AIDS takes a big toll on human lives in Nigeria and even the economy at large. This could have corresponding consequences on the human capital stock in Nigeria as well as potential labour force or manpower of the nation. In addition, catering for the people living with HIV/AIDS could take away a lot of investible funds from both individual (the infected person, relations and friends) and government for subsidizing and providing of drugs for the infected citizens.

A country could lose productivity, manpower, agricultural output, in both the infected person and their care-givers. Reducing the prevalence would help enhance the productivity of the country. But despite the importance attached to the reduction and efforts made by both local and foreign agencies at stemming the tide of this scourge, HIV/AIDS has remained on the increase and its impact on economic growth in Nigeria is alarming. This study is an attempt to find out the impact of HIV/

*Corresponding author: Ojiya Emmanuel Ameh, Lecturer, Department of Economics, Federal University Wukari, Taraba State, Nigeria; Tel: 347-688-8931; E-mail: ojiyaenoch2000@gmail.com

Received September 22, 2017; Accepted October 06, 2017; Published October 13, 2017

Citation: Sunday OA, Ameh OE, Uchechukwu A (2017) Assessment of the HIV AIDS Impact on the Nigerian Economy Performance: An Empirical Analysis. AIDS Clin Res 8: 736. doi: 10.4172/2155-6113.1000736

Copyright: (c) 2017 Sunday OA, et al. This is an open-access article distributed under the terms of the Creative Commons Attribution License, which permits unrestricted use, distribution, and reproduction in any medium, provided the original author and source are credited. 
AIDS on the Nigerian economy. Furthermore, considering the literatures reviewed in this study, there are noticeable gaps that this research is meant to bridge. Most of the researchers did not use Nigerian economy in particular as a case study, and the only research that was conducted in Nigeria did not cover Nigeria as a whole but just one state [4]. However, this research will hopefully bridge this gap as it focuses on Nigerian economy as a whole. Most of them used some methods other than the OLS linear regression technique which is the most efficient, effective and reliable among most methods of data analysis. However, this research shall adopt the all-time reliable OLS linear regression technique as a tool for data analysis, alongside other test like unit root test, cointegration analysis and an error correction mechanism, etc.

The scope of 1990-2015 was deliberately chosen to coincide with the period those infected with HIV/AIDS from 1986 would have become incapacitated by the thus leading to loss of productivity, hence a fall in gross domestic product of the country. Two hypotheses are formulated to be empirically tested at the end of this study. They are as follows:

$\mathrm{H}_{01}$ : HIV/AIDS has no significant impact on economic growth in Nigeria.

$\mathrm{H}_{02}$ : Government expenditure on health has no significant impact on HIV/AIDS in Nigeria.

The remaining part of this study is sectionalized as follows: Section two of the study shall briefly discuss some key concepts as well as theoretical framework for the study; section three is methodology with section four devoted to data presentation, analysis and discussion of empirical results. Finally section five is conclusion and policy recommendations.

\section{Conceptual Framework/Literature Review}

\section{Conceptual framework}

Human Immune Deficiency Virus (HIV) is a virus that causes many different illnesses such as common cold (catarrh) measles, hepatitis, chicken pox, polio and rabies. The Human Immune Deficiency Virus (HIV) that causes AIDS is a small germ that is too small to see with an ordinary microscope. It is so small that there could be 230,000 at a point of a pen or on a full stop at the end of a sentence. It takes only a few of those viruses to enter a human body to become infected and later develop to AIDS [5]. During the initial infection, a person may experience a brief period of influenza-like illness. This is typically followed by a prolonged period without symptoms. As the illness progresses, it interferes more and more with the immune system, making the person much more likely to get infections, including opportunistic infections and tumors that do not usually affect people who have working immune systems. When the body can no longer fight infection, the disease is known as AIDS, which stands for Acquired Immune deficiency Syndrome. On average, it takes more than 10 years to progress from initial HIV infection to AIDS. Acquired Immune Deficiency syndrome (AIDS) is defined in terms of either a CD4+ T cell count below 200 cells per or the occurrence of specific diseases in association with an HIV infection. In the absence of specific treatment, around half of people infected with HIV develop AIDS within ten years [6]. The most common initial conditions that alert to the presence of AIDS are pneumocystis pneumonia (40\%), cachexia in the form of HIV wasting syndrome $(20 \%)$ and esophageal candidiasis. Other common signs include recurring respiratory tract infections.

\section{Transmission of HIV/AIDS}

HIV is transmitted by three main routes: sexual contact, exposure to infected body fluids or tissues and from mother to child during pregnancy, delivery, or breastfeeding (known as vertical transmission). There is no risk of acquiring HIV if exposed to feces, nasal secretions, saliva, sputum, sweat, tears, urine, or vomit unless these are contaminated with blood. It is possible to be co-infected by more than one strain of HIV - a condition known as HIV super infection. In order to be infected, the virus must enter a person's bloodstream (HIV cannot survive outside the body). HIV is transmitted from one person to another through: unprotected sexual intercourse (vaginal, anal or oral), shared needles or equipment for injecting drugs, unsterilized needles for tattooing, skin piercing or acupuncture, pregnancy, delivery and breast feeding (i.e., from an HIV-infected mother to her infant) and occupational exposure in health care settings.

\section{The concept of economic growth}

Economic growth represents the expansion of a country's potential GDP or national output. According to Todaro [7], economic growth refers to an increase in a country's national output of goods and services or increase in the volume of output of goods and services within a specific period. According to Lewis, it means the increase of output per head of population since the main aim of economic growth is to raise the standard of living of the people.

\section{The impact of HIV/AIDS on economic growth}

The impact of the HIV/AIDS epidemic on the economy has been a concern since the beginning of the pandemic. Some believe that the HIV/AIDS epidemic is responsible for slowing the rate of growth of the gross national product of many heavily affected/infected countries and that in some cases, GNP growth could decrease by more than 1 percentage point for every $10 \%$ HIV prevalence. Others hold the view that HIV/AIDS has had little impact on most nations' macroeconomic success. It is difficult to estimate empirically the effect of HIV/AIDS on economic performance since so many factors other than HIV/AIDS affect economic growth. The countries most seriously affected by the epidemic in most of African and Latin American countries are also equally faced with drought, war and other problems. Development, as set out in the Declaration on the Right to Development (General Assembly Resolution 41/128, annex), "is a comprehensive economic, social, cultural and political process, which aims at the constant improvement of the well-being of the entire population and of all individuals on the basis of their active, free and meaningful participation". While economic growth is an important element of the development process, it is not by itself an adequate yardstick of development. A fuller understanding of the effects of HIV/AIDS on the prospects for development requires looking beyond the conventional indicators of macroeconomic performance.

The HIV/AIDS epidemic can affect the economy in a number of ways:

(a) The AIDS epidemic will slow or re-verse growth in the labour supply. The economic impact can vary according to the sector of the economy, the degree to which HIV/AIDS affects hard-toreplace skilled labour and whether or not there is a substantial pool of "surplus labour".

(b) Savings and investments of families will be reduced owing to the increase in HIV/AIDS-related health expenditures. If children's education, health and nutrition suffer as a result, prospects for long-run economic growth and development will decline.

(c) The AIDS epidemic may also divert public spending from investments in physical and human capital to health 
expenditures, leading over time to slower growth of the gross domestic product. Foreign and domestic private investment might also decline if potential investors become convinced that the epidemic is seriously undermining the rate of return to investment.

(d) The HIV/AIDS epidemic may also deepen the poverty of the most affected countries by decreasing the growth rate of per capita income and by selectively impoverishing the individuals and families that are directly affected.

Cohen, among others, stresses the effect of HIV on the size of the working population, which tends to reduce total output and worsen the dependency ratio [8]. More children and elderly people may have to be supported by a smaller active labour force. In addition, the composition of the labour force may change with respect to skills, education and experience, which would decrease the productivity of labour. Theodore, in a model applied to several Caribbean countries, identified four channels through which HIV/AIDS may affect the economy: the production channel; the allocation channel; the distribution channel; and the regeneration channel (Figure 1). The production channel refers to the mechanisms through which HIV/AIDS affects the main factors of production - labour and capital - causing the production process to be less fruitful than it would have been in the absence of HIV/AIDS. The second channel through which HIV/AIDS may affect the economy is the allocation channel. One of the most important functions of the economic system is to ensure an efficient allocation of resources.

HIV/AIDS reroutes some of those resources to medical expenses and away from other productive uses. The third assumed channel through which HIV/AIDS affects the economy is the distribution channel, specifically, the distribution of income. In the face of an epidemic that increases health expenditures and weakens the income base, the lowest income groups may fare the worst. While the rich may have other assets - savings, land or capital - often the only productive asset of the poor is their own labour, which HIV/AIDS attacks. The upper income groups, though they are also affected, may be better placed to protect themselves and better able to afford treatment. Thus, the HIV/AIDS epidemic has the potential not only to affect all groups but also to widen the gap between different social strata. The fourth channel, the regeneration channel, refers to the investments in human capital, physical capital and new technology that are needed to keep the economy growing. If the HIV/AIDS epidemic compromises the saving capacity and the human capital of the economy, it will undercut the process of economic development.

\section{Theoretical framework}

Economic theory postulates different theories in the discussion of the process of economic growth and development. However, for the purpose of this study, the popular Harrod-Domar Model is adopted for its simplicity in analyzing the production function.

\section{Harrod-Domar model}

Economic growth is explained as a combined result of the rate of savings and the resultant physical capital accumulation on one hand and the capital-output ratio (physical production of new investment) on the other. Harrod-Domar is the simplest and best known production function used in the analysis of economic development. It explains the relationship between growth and unemployment in advanced capitalist societies. The model is also employed in developing countries as an easy way of studying the relationships between growth and capital requirements. It explains the differences in growth performances between countries and it allows for the prediction of growth estimates for a nation. It thus suggest that savings provides the funds which are borrowed for investment purposes. The economy's rate of growth depends on: the level of savings and the savings ratio; the productivity of investment that is, economy's capital-output ratio. In some further analysis Harrod-Domar is applied to explain the business cycles. Economic growth depends on the amount of labour and capital. In developing countries that have an abundant supply of labour, it is bound to experience accelerated growth and development in all sectors of the economy. It is a lack of physical capital that holds back the wheel that drive economic growth and economic development in most of Sub-Saharan Africa.

\section{Empirical review}

Daudu investigated the effect of HIV/AIDS on Farm Families in Makurdi L.G. using frequency distribution, percentages and Chi-square [4]. They basically used primary data, and conclude that HIV/AIDS has serious adverse effect on the productivity, farm income and standard of living of the affected farm families. Education of rural households on the danger of HIV/AIDS and ways of preventing or minimizing its spread is recommended by the study.

Some researchers carried out a study between February and June 2014, to ascertain the awareness and response of University students to HIV/AIDS Voluntary Counseling and Testing. A total of 464 students were interviewed with the aid of structured questionnaire. Data were analyzed for simple descriptive (mean and mode) and inferential (chi-

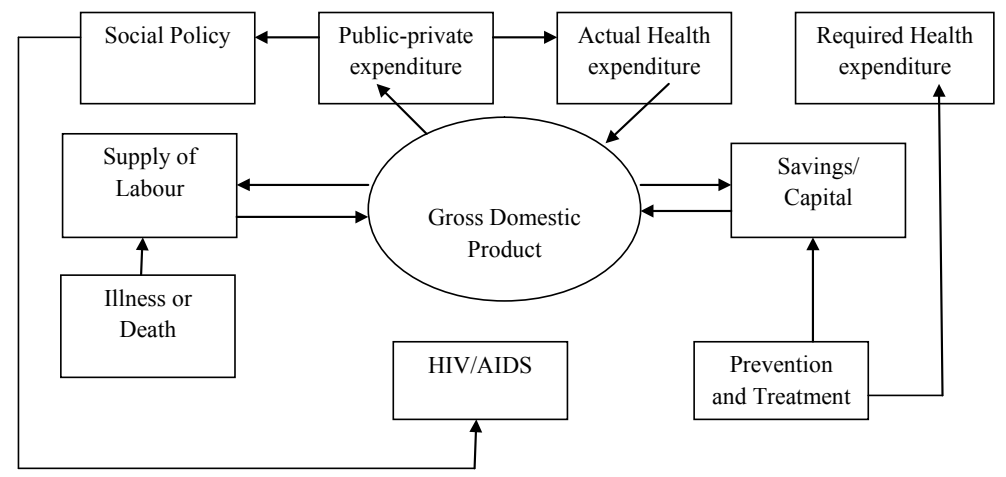

Source: Karl Theodore, "HIVIAIDS in the Caribbean: economic issues-impact and investment response". Commission on Macroeconomics and Health Working Paper Series, Paper No. WG1:1 (Cambridge, Massachusetts, Harvard University, Center for International Developments; and Geneva, World Health Organization, 2001)

Figure 1: Conceptual framework for the impact of HIVIAIDS on the economy. 
square) statistics using the Statistical Package for Social Sciences (SPSS) for Windows. Results revealed that $52.2 \%$ of the respondents were females while $47.8 \%$ were males. Most respondents were between ages 20-24 (70.5\%) and single (90.8\%).

Dixon et al. assessed the impact of the HIV epidemic on growth by means of an econometric model from 1960 to 1998 [9]. They used panel data of 41 African countries over the period from 1960 to 1998. They found out that a reduction of 1.3 per cent in economic growth at an HIV prevalence of $20 \%$ increases in those countries annually. Education and sensitization on the epidemic and Government reviewing its policy on the disease was the recommendation of the study.

Similarly, Zakari and Abdullahi examined economic impact of HIV/AIDS and stigmatization on women in Nigeria; a challenge for the actualization of Millennium Development Goals (MDGs) [10]. The study was carried out using primary data among groups of Nigerian women. The data were analyzed using simple percentage method. The results of the study revealed that negative presentation by some medical personnel and the sensational captions by the Nigerian mass media on the so-called dead sentence nature of HIV/AIDS epidemic made it so scary that people found it difficult to accept its presence and so stigmatize people especially women with the disease. However the study recommends that religious organizations, government and non-governmental organizations intensify sensitization efforts towards combating the epidemic.

Sharp investigated the Economic impact of HIV/AIDS in Russia; current trends and perspectives [11]. The study was carried out using secondary data sourced from World Bank database. The data was analyzed using mathematical ILO model. The results of the study revealed that HIV/AIDS reduce human capital formation within and across generations, changes the population age composition, reduce labour force productivity. The study recommends that the government of Russia should make the epidemic among its major objectives in achieving macroeconomic growth and stability.

Cuddington and Hancock used a neoclassical one sector, two factor growth models to predict economic growth in Tanzania and Malawi [12]. They found that over the period 1985-2010, average annual GDP growth would be reduced by $1.1 \%$ points in Tanzania and 1.5 percentage points in Malawi. Also, should AIDS treatment costs be entirely financed from savings, the AIDS epidemic would reduce per capita GDP growth by 0.3 percentage points and 0.1 percentage points in Malawi and Tanzania respectively. The study is important as it developed a simple but tractable framework for analyzing the effects of HIV/AIDS on the growth paths of potential gross domestic product and per capita GDP In the same vein, in Southern African Countries, rates of population growth have already decreased by between $0.6 \%$ and $1.5 \%$ by 2000 .

Kambou investigated the impact of AIDS in Cameroon, applying an eleven-sector computable general equilibrium (CGE) model for the period 1986-1991 [13]. They conclude that over the period, the loss of an urban worker had seven times the negative impact on production as would the loss of a rural worker and GDP growth rate was reduced by $1.9 \%$ per year.

\section{Methodology}

\section{Variables and data source}

Variables for this study are gross domestic product (proxy for economic growth) used as dependent variable with HIV/AIDS and government expenditure on health as independent variables respectively. The data for the study were secondary in nature obtained from the World Bank Development Indicators database and Central Bank of Nigeria (CBN) statistical bulletin, 2015 edition [14,15]. The time series data cover a 30-years period ranging from 1990-2015.

\section{Model specification}

A multiple regression model is used with economic growth proxied by gross domestic product (GDP) as dependent variable while HIV AIDS and government expenditure on health (Gxp-Hlt) were taken as independent variables The functional form of the model is thus specified as:

$$
\mathrm{GDP}=f\left(\mathrm{HIV} \_\mathrm{AIDS}, \mathrm{Gxp} \_\mathrm{Hlt}\right)
$$

For the purpose of estimation we shall restate the above functional in an econometric form as:

$$
\mathrm{GDP}=\beta_{0}+\beta_{1}\left(\mathrm{HIV} \_ \text {AIDS }\right)+\beta_{1}\left(\mathrm{Gxp} \_ \text {Hlt }\right)+\mu_{\mathrm{t}}
$$

The estimated models are further transformed into log-linear form. This is aimed at reducing the problem of multi-collinearity among the variables in the models. Thus the log-linear models are specified as shown: LnGDP $=\beta_{0}+\beta_{1}($ HIV_AIDS $)+\beta_{2}\left(G x p \_H l t\right)+\mu_{t}$

Where:

$\mathrm{GDP}=$ Gross Domestic Product (proxy for the growth of the Nigerian economy)

HIV_AIDS=Human Immune Virus/Acquired Immune Deficiency Syndrome

Gxp-Hlt=Government expenditure on Health

$\mu \mathrm{t}=$ Error term

$\beta_{0}=$ Intercept

$\beta_{1}$ and $\beta_{2}=$ Slope of the regression equation

Our a priori expectations are: $\beta_{1}$ and $\beta_{2}>0$

\section{Economic A priori (expected results)}

This specifically has to do with sign expectation set by economic theory and it is expected that parameters in this model have the correct signs and sizes that conform to economic theory. If they carry the expected signs, then the hypothesis is accepted otherwise they are rejected. On a priori ground, it is expected that increase in GDP should stem from a fall in the rate of infection through HIV/AIDS, while government expenditure on health is expected a priori to come out with a positive sign. This means that an increase in government spending on health is expected to reduce the scourge of HIV/AIDS hence increase in productivity (economic growth) in Nigeria.

\section{Data presentation}

Data and variables for this study is the gross domestic product (GDP), a measure of the productivity and economic performance of a country. On the other side of the equation are data on HIV-AIDS scourge and government expenditure on health as independent variable. Data for the study is essentially sourced from World Bank Development Indicators and Central Bank of Nigeria Statistical Bulletin [14]. It is presented in the appendix page for reference.

\section{Empirical Result and Analysis}

\section{Stationarity test}

This study commences its investigation by first testing the properties of the time series used for analysis. A unit root test was performed on 
each of the variable since the variables are time series in nature and prone to fluctuations. The test is conducted using two different unit root models. That is, the Augmented Dickey Fuller (ADF) model and the Philips-Perron (PP) model. The essence of using the two tests is for confirmatory testing. The result of the unit root test is shown in Table 1.

The Augmented Dickey Fuller and Philip-Perron unit root results as presented in Table 2 above showed strong evidence(s) that all the variables were stationary either at first difference I (1) or at level I (0). For clarity, all variables under Philips-Perron Unit root test became stationary at their first difference. This is achieved when the ADF or PP $t$-statistic in absolute terms is greater than the critical values, thereby proving the null hypothesis of 'there is unit root' wrong, it is therefore clearly revealed from the $\mathrm{ADF}$ and $\mathrm{PP}$ tests results that all the variables under investigation Gross Domestic Product (GDP), HIV_AIDS and Government Expenditure on Health (Gxp_Hlt) met the condition of stationarity hence we can proceed to estimate Johansen cointegration test.

\section{Co-integration (long run) analysis}

Table 3 indicates one co-integration equations at those ranks where the values of the trace statistics exceed the $5 \%$ critical values. This was confirmed by the results of the maximum eigenvalues where cointegration exists at ranks where the value of eigenvalues is at least 0.5. The discovery here is that both the trace and max-eigenvalue statistic yielded one cointegrating equation. This is in agreement with economic theory which states that cointegration exists where there is at least one cointegrating equation, hence we conclude that the series
- gross domestic product, HIV_AIDS and government expenditure on have long run relationship, i.e., they can both walk together for a long time without deviating from such established path

\section{OLS empirical result}

Since variables in the model are stationary and possess long run relationship, an economic interpretation of the relationship between gross domestic product and the independent variables can be obtained through an ordinary least square. The OLS regression result with the series gross domestic product inflation rate and exchange rate is presented below.

\section{Interpretation and Discussion of Findings}

The Ordinary Least Square (OLS) logged multiple regression result is as presented in Table 4 with the equation. $\log (40.12649)=\alpha_{0}+\alpha_{1} \log$ $(-0.777654)+\alpha_{2} \log (0.197421)+u_{t}$

The OLS results showed that the intercept (constant) was positive and highly significant, such that when all other variables are at the zero level or held constant, the intercept coefficient value is at a positive unit of 40.12649. The HIV_AIDS coefficient was statistically significant but had an inverse relationship with economic growth (GDP), it is such that a unit increase in the HIV/AIDS infection leads to about 77 billion naira decline in productivity (i.e. gross domestic product) in Nigeria within the period referenced. The negative relationship between HIV/ AIDS infection and economic growth is consistent with economic theory, that a rise in the rate of HIV/AIDS infection leads to a decline in economic growth as man-hour that should have been invested into meaningful economic activities is lost due the pandemic.

\begin{tabular}{|l|c|c|c|}
\hline Variable & $\begin{array}{c}\text { Level } \\
\text { t-statistic }\end{array}$ & $\begin{array}{c}\mathbf{1}^{\text {st }} \text { Difference } \\
\text { t-statistic value }\end{array}$ & Order of Integration Critical Value \\
\hline Log (GDP) & Non-stationary & -3.843603 & -2.991878 \\
\hline Log (HIV_AIDS) & -4.139778 & ---- & -2.998064 \\
\hline Log (Gxp_HIt) & -3.487248 & ----- & -3.020686 \\
\hline
\end{tabular}

Source: Author's computation using Eviews 8.0

Table 1: Augmented dickey fuller unit root test with intercept.

\begin{tabular}{|l|c|c|c|}
\hline Variable & $\begin{array}{c}\text { Level } \\
\text { t-statistic }\end{array}$ & $\begin{array}{c}\text { 1st Difference } \\
\text { t-statistic value }\end{array}$ & Order of Integration \\
\hline Log (GDP) & Non-stationary & -3.843603 & -2.991878 \\
\hline Log (HIV_AIDS) & Non-stationary & -3.047500 & 2.991878 \\
\hline Log (Gxp_HIt) & Non-stationary & -11.64574 & 2.991878 \\
\hline
\end{tabular}

Source: Author's computation using Eviews 8.0

Table 2: Philip-Perron unit root test with intercept.

\begin{tabular}{|c|c|c|c|c|}
\hline Trace Statistic & $\mathbf{5 \%}$ critical value & Prob. Value & Max- Eigen statistic & $\mathbf{5 \%}$ critical value \\
\hline 36.24198 & 29.79707 & 0.0079 & 22.77295 & 21.13162 \\
\hline Trace test indicates 1 cointegrating eqn(s) at the 0.05 level & & Series have long-run relationship \\
\hline Max-eigenvalue test indicates 1 cointegrating eqn(s) at the 0.05 level & Series have long-run relationship \\
\hline
\end{tabular}

Source: Author's computation using E-views 8.0

Table 3: Co-integration table (Series tested: GDP, HIV_AIDS and Gxp_HIt).

\begin{tabular}{|c|c|c|c|}
\hline Variable & Coefficient & Std. Error & Prob. \\
\hline C & 40.12649 & 2.444436 & 16.41544 \\
\hline LOG(HIV_AIDS) & -0.777654 & 0.198074 & -3.926085 \\
\hline LOG(GEH) & 0.197421 & 0.016599 & 11.89370 \\
\hline
\end{tabular}

R-squared/Adjusted R-squared: (0.874282/0.863350)

F-statistic/Prob(F-statistic): 79.97466/0.000000

Durbin-Watson stat: 1.033390

Source: Author's computation from Eviews 8.0 
The second independent variable (government expenditure on health) has a positive and significant impact on economic growth during the period under reference. Empirical evidence reveals that, a billion naira increase in government expenditure on health contributed about 17 billion naira increment in gross domestic product (economic growth) between 1990 to 2015 . This is true to the extent that this spending on health could translate to better health service delivery to HIV/AIDS victims which will lead to a decline in the rate of infection thus increasing aggregate productivity and economic growth in the long run. This finding is equally in line with economic theory that government spending has the potential of increasing the rate of growth of an economy.

\section{Model Appropriateness}

\section{Interpretation of $\mathbf{R}^{2}$, adjusted $\mathbf{R}^{2}$ and F-statistics}

The coefficient of determination indicated by $\left(\mathrm{R}^{2}\right)$ indicates that about $87 \%$ of the variations in gross domestic product (GDP) is explained by the model, while the remaining $13 \%$ is explained by other variables which were not captured by the model but are included in the disturbance variable (i.e., the error term). On the basis of this, we may conclude that the estimated model has a good fit. The overall regression result measured by F-statistic (Prob. 0.00000) is significant, indicating a good fit for the model.

\section{Autocorrelation test}

Autocorrelation refers to the existence of a relationship between error terms across observations of a time series. In our study, autocorrelation is going to be tested using the Breusch-Godfrey serial correlation LM test. The Durbin-Watson test is not used because it is biased. The test results are shown in Table 5.

From the test results presented on Table 5, the probabilities of both

\begin{tabular}{|c|c|c|c|}
\hline F-statistic & 3.223307 & Prob. F (2,21) & 0.0601 \\
\hline Obs*R-squared & 6.106836 & Prob. Chi-Square (2) & 0.0472 \\
\hline
\end{tabular}

Source: Author's computation using Eviews 8.0

Table 5: Breusch-Godfrey serial correlation LM test.

\begin{tabular}{|c|c|c|c|}
\hline F-statistic & 0.542947 & Prob. F (2,23) & 0.5883 \\
\hline Obs*R-squared & 1.172189 & Prob. Chi-Square (2) & 0.5565 \\
\hline Scaled explained SS & 0.682677 & Prob. Chi-Square (2) & 0.7108 \\
\hline
\end{tabular}

Source: Author's computation using Eviews 8.0

Table 6: Heteroskedasticity test- Breusch-Pagan-Godfrey. the F-statistic $(0.0601)$ is greater than 0.05 . Therefore, $\mathrm{H}_{\mathrm{o}}$ is not rejected, meaning autocorrelation is absent.

\section{Heteroscedasticity test}

In order to ensure that the residuals are randomly dispersed throughout the range of the dependent variable, heteroscedasticity test is used. In the presence of heteroscedasticity, the distributions of the OLS parameters are no longer normal. Heteroscedasticity is tested in this study using the Breusch-Pagan-Godfrey test. The decision rule is to reject the null hypothesis if the probability of the F-statistic and observed $R^{2}$ are less than 0.05 , meaning heteroscedasticity is present.

\begin{tabular}{|c|c|c|c|}
\hline Year & GDP & HIV_AIDS & Gxp_HIt \\
\hline 1990 & $19,680,406,952,600.00$ & 140000 & 0.50 \\
\hline 1991 & $19,558,811,442,400.00$ & 170000 & 0.62 \\
\hline 1992 & $19,643,642,967,100.00$ & 200000 & 0.15 \\
\hline 1993 & $20,054,269,318,900.00$ & 230000 & 3.87 \\
\hline 1994 & $20,236,715,708,300.00$ & 260000 & 2.09 \\
\hline 1995 & $20,174,494,087,100.00$ & 290000 & 3.32 \\
\hline 1996 & $21,181,948,915,400.00$ & 300000 & 3.02 \\
\hline 1997 & $21,775,521,442,700.00$ & 300000 & 3.89 \\
\hline 1998 & $22,366,866,252,100.00$ & 290000 & 4.74 \\
\hline 1999 & $22,472,938,336,300.00$ & 280000 & 16.64 \\
\hline 2000 & $23,668,070,182,400.00$ & 260000 & 15.22 \\
\hline 2001 & $24,712,084,188,700.00$ & 250000 & 24.52 \\
\hline 2002 & $25,647,349,633,900.00$ & 240000 & 40.62 \\
\hline 2003 & $28,302,923,550,900.00$ & 230000 & 33.27 \\
\hline 2004 & $37,851,134,166,500.00$ & 220000 & 34.20 \\
\hline 2005 & $39,154,979,623,600.00$ & 210000 & 55.66 \\
\hline 2006 & $42,369,981,241,000.00$ & 210000 & 62.25 \\
\hline 2007 & $45,263,172,340,100.00$ & 210000 & 81.91 \\
\hline 2008 & $48,101,292,603,600.00$ & 210000 & 98.22 \\
\hline 2009 & $51,436,836,336,000.00$ & 210000 & 90.20 \\
\hline 2010 & $55,469,350,300,000.00$ & 210000 & 99.10 \\
\hline 2011 & $58,180,351,900,000.00$ & 210000 & 231.80 \\
\hline 2012 & $60,670,050,500,000.00$ & 210000 & 197.90 \\
\hline 2013 & $63,942,845,600,000.00$ & 210000 & 179.99 \\
\hline 2014 & $67,977,459,000,000.00$ & 210000 & 195.98 \\
\hline 2015 & $69,780,692,720,000.00$ & 210000 & 257.72 \\
\hline & & & \\
\hline
\end{tabular}

Source: World Bank Development Indicators and Central Bank of Nigeria Statistical Bulletin (2015)

Table 7: Variables used in the study (GDP and Gxp_Hlt expressed in billions of naira).

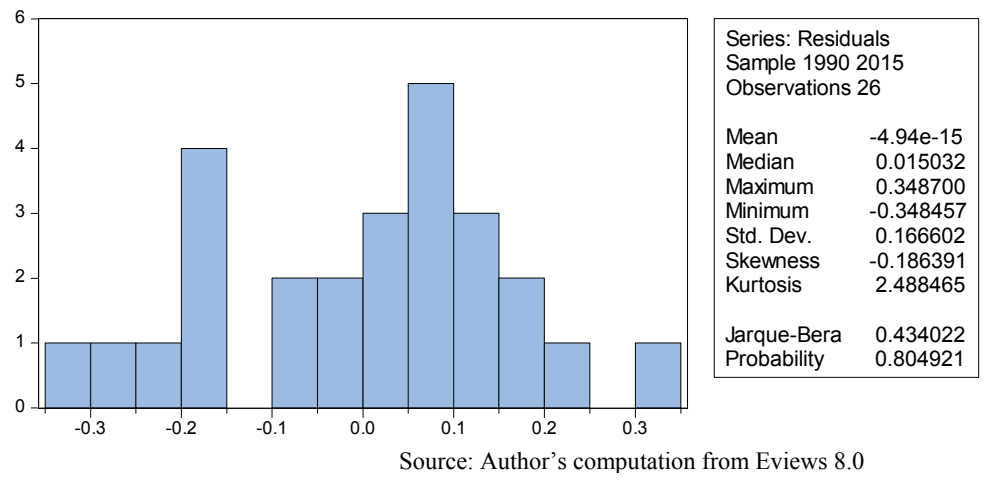

Source: Author's computation from Eviews 8.0

Figure 2: Diagnostic test result: Normality test 
On the other hand, if the probability of the F-statistic and observed $R^{2}$ are greater than 0.05 , we do not reject the null hypothesis, implying that there is no heteroscedasticity. As such, errors are homoscedastic. The test results are shown in Table 6.

From the test results presented in the Table 6 above, both the probabilities of F-statistic (05883) and the R-squared (0.5565) are higher than 0.05 indicating the absence of heteroscedasticity. Therefore, the errors are homoscedastic. The long run results succeed all tests and thus useful for analysis and forecasting (Figure 2).

The Jarque-Bera test is used to detect normality of model. This test first finds the skewness and kurtosis of the OLS residuals. The test is conducted to check whether the error term follows the normal distribution. The normality test adopted is the Jarque-Bera (JB) statistics. Looking at the histogram, the study observes that the residual is normally distributed because of the insignificant probability value of 0.804921 (Table 7).

\section{Summary, Conclusion and Recommendations}

Human Immunodeficiency Virus/Acquired Immune Deficiency Syndrome (HIV/AIDS) is a problem affecting all countries including Nigeria. It is no longer only a health issue but a substantial threat to socio-economic development, imposing a heavy burden first on families, then on communities and eventually economies. The impact of the pandemic is already being felt in most countries of the world: UNAIDS estimated that in 2003, about 38 million persons were HIVpositive worldwide and almost 26 million were workers between the ages of 15 and 49 . This implies that the most productive age group is most affected and this has implications for families and economies in terms of income, employment and productivity. It is in view of the foregoing that this study has attempted to evaluate the impact of HIV/ AIDS on the performance of the Nigerian economy between 1990 to 2015. A pre-test for stationarity of the data set was determined using the Augmented Dickey Fuller and Philips-Perron unit root test. The Johansen co-integration test was also utilized to find out if the variables have long-run association while the OLS technique was employed to ascertain the effects and impact of the independent variables on productivity and the performance of the Nigerian economy.

Empirical analysis from the adopted econometric techniques revealed a number of profound findings: First and foremost is the fact that HIV/AIDS had a significant negative impact on productivity and by implication economic growth during the period studied. Similarly, government spending on health had a significant positive impact on productivity (economic growth) in Nigeria between 1990-2015.

In line with the objective of this study, the study revealed that HIV/ AIDS has a negative impact on productivity (economic growth) in Nigeria between 1990 to 2015. This without doubt will be felt much more in the years to come. For example, the study showed that the effect of HIV/ AIDS infection has tremendously hindered growth in output/productivity implying that in the long run, productivity may decline. Besides the study showed a high budgetary implication of taking care of those infected. Therefore, the government should urgently elicit the cooperation of all relevant stakeholders and set up policies for the prevention of the estimated output loss that could result if the disease prevalence is not controlled. Also, the financing of prevention and intervention programs will have a serious impact on public spending. Furthermore, the study recommends the need for enlightenment campaigns for awareness and stern the incidence of new infections. More importantly infected individuals should have access to anti-retroviral drugs at the primary health centres (PHC) to reduce time and resources in care-giving.

\section{References}

1. Nasiji S (1986) Attaining millennium development goals (MDGs) through HIV/ AIDS education for students with hearing impairment in Nigeria. Millennium development goals (MDGs): Issues and Strategies. School of Arts and Social Sciences (SASS) KSCOE, Ankpa.

2. NACA (2012) National agency for the control of AIDS annual report.

3. Akpochafo WP (2010) Teaching of social problems in Nigeria schools. Benin city Justice-Jeco printing and publishing Global.

4. Daudu S (2003) The effect of HIVIAIDS scourge on farm families in Markudi L.G Benue state. J Hum Ecol 4: 87-98.

5. Garland A (1999) Moving Nigeria from low coverage to universal health coverage: Health system challenges, equity and the evidence - Inaugural Lecture. Series IV, Nsukka, UNN Press.

6. Kallings LO (2008) The first postmodern pandemic: 25 years of HIVIAIDS. In J Med 263: 218-243.

7. Todaro (2000) Economic Development, 7th Edition, New Delhi, Pearson Education.

8. Cohen WJ (1997) Office of the secretary of defense. Historical Office Washington D.C.

9. Dixon S, McDonald S, Jennifer R (2001) AIDS and economic growth in Africa: A panel data analysis. J Int Dev 13: 411-426.

10. Zakari A, Abdullahi A (2013) Economic impact of HIVIAIDS and stigmatization on women in Nigeria. Acad J Interdiscip Stud 3: 16-24

11. Sharp S (2005) The economic impact of HIVIAIDS in Russia: Current trends and perspectives. HIVIAIDS in Russia and Eurasia, pp: 77-102.

12. Cuddigton JT, Hancock JD (1995) The macroeconomic impact of AIDS in Malawi: A dualistic labour economy. J Afr Econ 4: 1-28.

13. Kambou E (1992) Analysis of the impact of HIVIAIDS in Cameroon. J Econ Dev 24: 66-80.

14. Central Bank of Nigeria (2015) Statistical Bulletin, 2015 edition.

15. World Bank (2015) World Bank development indicators 2015. World Bank, Washington, D.C. 